\title{
Líkamsskynjunarröskun
}

\section{Helstu einkenni, algengi, greining og meðferð}

\author{
Hrefna Harðardóttir ${ }^{1}$ lýðheilsufræðingur \\ Arna Hauksdóttir ${ }^{1}$ sálfræðingur \\ Andri Steinpór Björnsson² sálfræðingur
}

${ }^{1}$ Miðstöð i lýðheilsuvísindum við læknadeild Háskóla Íslands,

²sálfræđideild Háskóla Íslands.

Fyrirspurnum svarar Hrefna Harðardóttir, hrh41@hi.is

\section{Inngangur}

Líkamsskynjunarröskun (LSR; body dysmorphic disorder) er geðröskun sem einkennist af áleitnum hugsunum um útlitsgalla sem er pó ekki til staðar, eða er smávægilegur. ${ }^{1}$ Prátt fyrir að saga líkamsskynjunarvanda teygi sig langt aftur í tímann hafa kerfisbundnar rannsóknir á röskuninni einungis verið stundaðar í um prjá áratugi. Pessi geðröskun er vangreind en hefur oft mikil áhrif á líf fólks. ${ }^{2}$ Mikilvægt er að pekkja röskunina og helstu einkenni og hvaða meðferð við henni er líklegust til að bera árangur. Jafnframt er mikilvægt að skima fyrir henni og greina í klínísku samhengi. Markmið pessarar yfirlitsgreinar er að gera grein fyrir stöðu pekkingar á LSR, algengi hennar og hvaða meðferð er vænlegust til árangurs samkvæmt rannsóknum, en jafnframt að rökstyðja mikilvægi skimunar fyrir henni og veita upplýsingar um mælitæki til skimunar og greiningar sem tiltæk eru á íslensku.

\section{Hvað er líkamsskynjunarröskun?}

Peir sem pjást af LSR verja oft mörgum tímum á dag í að hugsa um einn eða fleiri útlitsgalla, sem pó eru ekki til staðar eða eru smávægilegir. Peir sem eru með LSR hafa til dæmis áhyggjur af húðinni (svo sem hrukkum, bólum og örum), hári (til dæmis að líkamshár líti ekki „rétt“ út) og nefi (lögun eða stærð pess), en áhyggjur geta pó beinst að hvaða líkamshluta sem er, svo sem maga, kynfærum eða tám. Sjúklingar geta orðið uppteknir af mismunandi líkamshlutum á ólíkum tímabilum og peir geta haft áhyggjur af mörgum "göllum“ á sama tíma. Rannsóknir benda til pess að meðal einstaklinga með LSR sé algengast að vera upptekinn af 5-7 líkamshlutum yfir ævina. ${ }^{3,4}$

\begin{abstract}
Á G R I P
Líkamsskynjunarröskun er geđröskun sem einkennist af áleitnum hugsunum um útlitsgalla sem er pó ekki til staðar. Röskunin kemur að jafnaði fram á unglingsárum og er kynjahlutfall nokkuð jafnt. Peir sem pjást af röskuninni eyða oft mörgum tímum á dag i að hugsa um útlit sitt og fylgir hugsununum yfirleitt áráttukennd hegðun, svo sem að líta endurtekið í spegil eða bera útlit sitt saman við útlit annarra. Vegið algengi röskunarinnar í almennu pýði er um $2 \%$ en er talsvert hærra i klínísku samhengi og á stofum húð- og lýtalækna. Hún hefur oft alvarlegar afleiðingar í för með sér, eins og mikla vanvirkni, skert lífsgæði, punglyndi og mikla sjálfsvígshættu. Lítið er vitað um orsakir röskunarinnar og hvaða pættir spá fyrir um framvindu hennar. Hugræn atferlismeðferð og SRI-lyfjameðferð skila mestum árangri, en ljóst er að fegrunaraðgerðir skila litlu og geta verið skaðlegar fyrir pessa skjólstæðinga. Í greininni eru upplýsingar um hvernig hægt sé að skima fyrir röskuninni og greina hana. Pörf er á frekari rannsóknum á líkamsskynjunarröskun og meðferð við henni.
\end{abstract}

https://doi.org/10.17992/lbl.2019.03.222

Pessari práhyggju fylgir næstum alltaf áráttukennd hegðun sem er ætlað að draga úr vanlíðan og peim kvíða sem fylgir hugsununum um útlitsgallann. Pessi hegðun getur verið tímafrek og um helmingur einstaklinga með LSR ver premur tímum eða meira á dag í hegðunina, og finnst erfitt að stjórna henni. ${ }^{5}$ Algengt er að einstaklingar með röskunina beri líkamshlutana sem um ræðir saman við aðra, athugi pá endurtekið í spegli eða snyrti sig óhóflega mikið. ${ }^{1}$ Um $87 \%$ sjúklinga með LSR spegla sig endurtekið og getur pað leitt til mikillar vanlíðunar. ${ }^{6}$ Einnig er algengt að peir hylji "gallana“, til dæmis með miklum farða, húfum, sólgleraugum eða klæðnaði. Slíkri öryggishegðun er ætlað að hindra að eitthvað slæmt gerist, til dæmis að peir verði sér til skammar eða að aðrir geri grín að peim vegna útlits peirra. ${ }^{7}$ Fólk með LSR upplifir mikinn ótta við höfnun og forðast oft félagslegar aðstæður, sem getur svo leitt til mikillar félagslegrar einangrunar. Í sumum tilvikum minnka kvíðaeinkenni tímabundið í kjölfar áráttuhegðunarinnar, sem leiðir til pess að hegðunin festist í sessi. 2,6

Einkenni LSR eru nokkuð svipuð hjá börnum og unglingum annars vegar og fullorðnum hins vegar. Börn og unglingar með pessa röskun upplifa einnig áleitnar hugsanir um eigið útlit sem og áráttukennda hegðun til að bregðast við pessum hugsunum. Röskunin dregur oft úr virkni og hefur mikil áhrif á félagsleg samskipti líkt og meðal fullorðinna og sýna erlendar rannsóknir að allt 
að 18-22\% unglinga með LSR hafi hætt í skóla sökum röskunarinnar. Unglingar hafa almennt meiri ranghugmyndir um eigið útlit en fullorðnir og er tíðni sjálfsvígstilrauna hærri hjá unglingum en fullorðnum. ${ }^{8,9}$

\section{LSR í greiningakerfum}

Ameríska geðlæknafélagið, APA (American Psychiatric Association) hefur reglulega gefið út greiningarkerfi á geðröskunum (DSM, Diagnostic and Statistical Manual of Mental Disorders) og kom fyrsta útgáfa pess út árið 1952. Árið 1980 var LSR fyrst tekin inn í DSM-III sem dæmi um líkömnunarröskun (atypical somatoform disorder) og bar pá heitið líkamslýtafælni (dysmorphophobia) og var hún án nokkurra greiningarviðmiða. Í endurbættri útgáfu (DSM-III-R) frá árinu 1987 var röskunin flokkuð sem líkömnunarröskun og fékk par nýtt nafn, líkamsskynjunarröskun (body dysmorphic disorder)..$^{10}$ Tvær breytingar voru gerðar með tilkomu fimmtu útgáfu af greiningarkerfinu, DSM-5. Samkvæmt DSM-5 fellur röskunin undir nýjan flokk innan greiningarkerfisins sem heitir áráttu- og práhyggjuröskun og skyldar raskanir (obsessive-compulsive and related disorders). Innan pess flokks eru meðal annars áráttu- og práhyggjuröskun (obsessive-compulsive disorder), hárplokkunarárátta (trichotillomania), húðkroppunarárátta (excoriation disorder) og söfnunarárátta (hoarding disorder). Til að greinast með LSR samkvæmt DSM-5 parf viðkomandi að upplifa áleitnar, neikvæðar hugsanir um útlitsgalla sem er pó ekki sýnilegur öðrum. Ef galli er til staðar er hann smávægilegur og áhyggjur af honum yfirdrifnar. Flest fólk finnur inn á milli fyrir óánægju með eigið útlit en til að aðgreina pessar „venjulegu“ áhyggjur frá LSR er miðað við að fólk eyði klukkustund eða meira á dag í prálátar hugsanir um útlit sitt. Viðkomandi parf að hafa brugðist við hugsunum um líkamslýtið með endurtekinni hegðun (til dæmis að athuga líkamshlutann í spegli, snyrta hann eða fela) eða endurteknum hugrænum aðgerðum (til dæmis að bera líkamshluta sinn saman við aðra) einhvern tíma á ferli röskunarinnar. Oft er slík hegðun áráttukennd, og viðkomandi telur sig pví knúinn til að bregðast við práhyggjufullum hugsunum með pessum hætti. pessum hugsunum og hegðun fylgir mikil vanlíðan og skerðing á mikilvægum sviðum lífsins, svo sem í félagslegum samskiptum, atvinnu og námi.

Í DSM-5 er litið svo á að ranghugmyndir fólks um eigið útlit liggi á rófi, allt frá góðu innsæi (pað telur mögulegt að hann eða hún hafi á röngu að standa um útlit sitt) til pess að hafa ranghugmyndir um „lýtið“ (mikil sannfæring um að hann eða hún líti svona út). ${ }^{1}$ Niðurstöður úr rannsókn á sjúklingum með LSR sýndu að $36 \%$ pátttakanda voru með núverandi ranghugmyndir um eigið útlit. Pegar einstaklingar með LSR sem bjuggu yfir góðu innsæi um eigið útlit voru bornir saman við pá sem hafa ranghugmyndir um eigið útlit reyndust peir síðarnefndu líklegri til að vera með alvarlega LSR. ${ }^{11}$ Í annarri rannsókn kom í ljós að innsæi hjá sjúklingum með LSR var mun verra en hjá peim sem eru með áráttuog práhyggjuröskun: 39\% sjúklinga með LSR voru með ranghugmyndir en $2 \%$ sjúklinga með áráttu- og práhyggjuröskun. ${ }^{12}$

LSR var fyrst skilgreind í ICD-10 (The International Classification of Diseases) sem gefið var út af Alpjóðaheilbrigðisstofnuninni (WHO) árið 1992. Samkvæmt nýjustu útgáfunni sem tók gildi í janúar 2017, er LSR flokkuð sem líkömnunarröskun, en líklegt er að hún verði flokkuð undir áráttu- og práhyggjuröskun og skyldar raskanir líkt og í DSM-5 í næstu útgáfu. ${ }^{13}$

\section{Orsakir LSR}

Algengast er að LSR komi fram hjá ungmennum um 12 ára aldur, við upphaf kynproska, og er hún talin tengjast kynpróun (sexual selection). ${ }^{2}$ Maðurinn er ein af peim tegundum sem velur sér maka meðal annars út frá útlitspáttum. Petta er pví eðlislægur áhugi, en pegar LSR próast hefur áhersla á útlit gengið út í öfgar, og sjúklingar með pessa röskun hafa bæði brenglaða sýn á eigið útlit auk pess sem útlit er farið að hafa alltof mikið vægi í lífi peirra. Röskunin kemur yfirleitt fram um pað leyti sem sjálfsmynd ungmenna tekur miklum breytingum, pau fara að aðgreina sig enn frekar frá öðrum, og á sama tíma að bera sig saman við aðra á svipuðum aldri. ${ }^{2,14}$ Í nútíma samfélagi fá ungmenni sterk skilaboð um að útlit skipti miklu máli. Lítið er vitað um orsakir LSR og pví er mikilvægt að komast að pví hvaða pættir pað eru sem spá fyrir um próun á LSR og ná pannig að greina áhættuhópa og geta komið í veg fyrir að hún próist.

\section{Algengi}

Geðlæknirinn Katharine A. Phillips gerði tvær rannsóknir á stórum úrtökum einstaklinga með LSR, annars vegar á 188 pátttakendum sem leituðu meðferðar hjá henni og hins vegar 200 pátttakendum sem tóku pátt í framskyggnri langtímarannsókn á ferli LSR. Hlutfall kvenna var 49\% í fyrrnefndu rannsókninni og 68,5\% í peirri síðarnefndu. ${ }^{3,15}$ Röskunin virðist koma fram að meðaltali um 16-17 ára aldur, en prátt fyrir pað hefur röskunin lítið verið rannsökuð hjá börnum og unglingum., ${ }^{4,14}$ Talið er að LSR sé vangreind, en algengt er að einstaklingar greini lækni eða sálfræðingi sínum ekki frá LSR-einkennum, meðal annars vegna pess að peir upplifa mikla skömm og ótta við neikvæð viðbrögð. ${ }^{16}$ Í 5 rannsóknum kom í ljós að enginn af peim sem greindust með LSR hafði áður fengið pá greiningu í sjúkraskrá. Sjúklingar með LSR sögðust ekki ræða um einkenni sín að fyrra bragði, jafnvel pótt peir teldu að LSR væri peirra meginvandi, nema ef spurt væri beint um útlitstengdar áhyggjur. ${ }^{5,17-20}$

\section{Almenn úrtök}

Hingað til hafa 7 rannsóknir metið algengi LSR á fullorðnu fólki í almennu pýði. Fjöldi pátttakenda var á bilinu 673-2552 og algengið mældist á bilinu 0,7\%-3,2\%. Vegið algengi LSR í pessum 7 rannsóknum var tæplega $2 \%$, sem pýðir að pessi röskun er mun algengari en margar aðrar raskanir sem hafa fengið mun meiri athygli, svo sem geðklofi og lystarstol. ${ }^{21}$ Rannsókn frá árinu 2015 benti til pess að tíðni röskunarinnar væri eilítið lægri samkvæmt viðmiðum í DSM-5 borið saman við fyrri útgáfu greiningarkerfisins (DSM-IV). ${ }^{22}$ Tvær rannsóknir hafa kannað algengi LSR meðal barna og unglinga í almennu pýði og var algengi 2,2\% og 1,7\%. Börn og unglingar sem voru með LSR upplifðu frekar einkenni alvarlegs punglyndis, félagsfælni og áráttu- og práhyggjuröskunar en pau sem voru ekki með einkenni LSR. ${ }^{23,24}$ 


\section{Háskólanemar}

Niðurstöður 8 rannsókna sem gerðar voru meðal háskólanema ( $n=101-1041)$ bentu til pess að algengi LSR væri nokkuð breytilegt og örlítið hærra en í almennu úrtaki. Algengið var á bilinu 1,2\%$5,8 \%$ og vegið algengi úr pessum rannsóknum var 3,3\%. ${ }^{21}$

\section{Klínisk úrtök}

Í premur rannsóknum meðal sjúklinga á göngudeild geðspítala, kom fram að algengi var á bilinu 3,2-11\% og var vegið algengi $5,8 \% .{ }^{21}$ Í annarri rannsókn sem var gerð meðal sjúklinga sem leituðu sér sálrænnar meðferðar á dagdeild var algengi LSR 7,2\% og lífstíðaralgengi $9 \%{ }^{25}$ LSR hjá fullorðnum sjúklingum sem eru á lokuðum geðdeildum hefur verið metin í fjórum rannsóknum og reyndist algengi par mjög breytilegt, eða á bilinu 1,9-16\%, og vegið algengi 7,4\%. Algengi meðal ungmenna á lokaðri geðdeild hefur verið metið í tveimur rannsóknum, og kom einnig fram breytileiki par, eða $14,3 \%$ og 6,7\% og vegið algengi 7,4\% ${ }^{21}$

\section{Algengi LSR á stofum lýta- og húðlækna}

Peir sem pjást af LSR líta yfirleitt ekki svo á að vandinn sé sálrænn, og sækja pví oft í fegrunaraðgerðir eða húðmeðferð til að laga "galla" sína. Algengi LSR hjá peim sem leita meðferðar á húðmeðferðarstofu er á bilinu 4\%-29\% og vegið algengi er 11,3\%. ${ }^{21}$ Ellefu rannsóknir hafa metið LSR hjá einstaklingum sem leita til lýtalækna. Algengið virðist liggja á víðu bili, eða 6\%-53\% og er vegið algengi úr pessum rannsóknum 13,2\%. ${ }^{21}$ Petta pýðir að stórt hlutfall peirra sem leita til húð- og lýtalækna geti í raun verið með LSR.

\section{LSR á Íslandi}

Eina birta rannsóknin á algengi LSR á Íslandi var gerð meðal einstaklinga sem sóttu meðferð í átröskunarteymi geðsviðs Landspítala. Pátttakendur voru 24 konur og greindust 37,5\% peirra með LSR. Pær sem greindust með röskunina voru líklegri til að greina frá sjálfsvígshugsunum og að hafa gengist undir lýtaaðgerð. ${ }^{26}$ Einnig má nefna rannsókn sem kannaði húðkroppunaráráttu hjá 55 háskólanemum á Íslandi og mat algengi LSR meðal peirra. Kom í ljós að 9\% pátttakenda sem greindust með húðkroppunaráráttu pjáðust einnig af LSR. ${ }^{27}$ Algengi líkamsskynjunarröskunar er pví breytilegt eftir pví í hvaða hópum hún er metin (hún er til dæmis hærri á stofum lýtalækna en í almennu pýði) og hvaða mælitæki eru notuð við greiningu (hún er til dæmis mæld hærri með skimunarlistum en klínískum viðtölum).

\section{Framvinda og lífsgæði}

Afturskyggnar rannsóknir á LSR benda til pess að röskunin sé að jafnaði langvinn án gagnreyndrar meðferðar. ${ }^{3,28,29}$ Tvær framskyggnar langtímarannsóknir hafa verið gerðar á framvindu LSR. Í annarri peirra var fólki með kvíðaraskanir (514 einstaklingum) fylgt eftir í allt að 8 ár, og var LSR einnig greind og fylgt eftir í peirri rannsókn. 3,3\% af pátttakendum greindust með LSR við upphaf rannsóknar, og voru líkur á pví að læknast af LSR 0,6 eftir fjögur ár og 0,76 eftir 8 ár. Pó ber að nefna að pátttakendur voru einungis 17 einstaklingar. ${ }^{30}$ Í framskyggnri langtímarannsókn á 200 einstaklingum með LSR voru líkurnar á pví að læknast af röskuninni einungis 0,14 eftir tvö ár og 0,20 eftir 4 ár. ${ }^{31}$

LSR getur haft mikil áhrif á pá sem pjást af röskuninni. Pær rannsóknir sem áður voru nefndar á tveimur stórum úrtökum fólks með LSR, benda til skertra lífsgæða meðal fólks með LSR. Um 23\% pátttakenda voru á örorkubótum, 38\% atvinnulausir og 77\% töldu að einkenni peirra hefðu neikvæð áhrif á náms- og starfsgetu sína. ${ }^{3,4}$ Einstaklingar með LSR voru líklegri til að vera einhleypir (31\%) og vera tekjulægri en peir sem eru ekki með röskunina. ${ }^{4}$ Á bilinu 27-31\% fólks með pessa röskun hafði ekki farið út úr húsi í viku eða lengur á ævinni af ótta við að vera dæmt af öðrum vegna útlitsgalla. ${ }^{3,4}$

Samkvæmt einni rannsókn höfðu 19\% einstaklinga með LSR hugsað um sjálfsvíg samanborið við 3\% án LSR, og höfðu 7\% með LSR reynt að fremja sjálfsvíg miðað við $1 \%$ án LSR. ${ }^{32}$ Önnur rannsókn sýndi að $31 \%$ pátttakenda með LSR og $4 \%$ pátttakenda án LSR höfðu haft sjálfsvígshugsanir, og höfðu 22\% einstaklinga með LSR reynt að fremja sjálfsvíg miðað við $2 \%$ pátttakenda án LSR. ${ }^{33}$ Sjálfsvígshugsanir og tilraunir hjá sjúklingum með LSR eru enn algengari í klínískum aðstæðum, og benda niðurstöður rannsókna til pess að algengi sjálfsvígshugsana sé á bilinu 78-81\% meðal einstaklinga með LSR og að 24-28\% peirra hafði reynt sjálfsvíg. ${ }^{3,34}$

Langtímarannsókn á 185 einstaklingum með LSR með fjögurra ára eftirfylgd sýndi að sjálfsvígstíðnin var 45 sinnum hærri en í almennu pýði en petta hlutfall er hærra en hjá fólki með átraskanir, punglyndi og geðhvörf. ${ }^{35}$ Рað er pví mikilvægt að meta sjálfsvígshættu fólks sem pjáist af pessari röskun.

\section{Fylgiraskanir}

Algengt er að einstaklingar sem eru með LSR sem meginvanda greinist einnig með aðrar geðraskanir. LSR hefur í för með sér mikla vanlíðan fyrir sjúklinginn og er alvarlegt punglyndi algengasta fylgiröskunin, en par er ævialgengi samsláttar (pað er greining á tveimur eða fleiri röskunum er til staðar) um $75 \%$ og fylgir áfengis- og fíkniefnamisnotkun par á eftir (á bilinu 30$50 \%) .36,37$ Önnur rannsókn sýndi að í 60\% tilvika var LSR undanfari áfengis- og vímuefnamisnotkunar, kom í kjölfar áfengis- og vímuefnamisnotkunar í 19\% tilvika og hófst um svipað leyti hjá $21 \%$. Meirihluti pessara einstaklinga (68\%) taldi að áfengis- og vímuefnaneysla hefði orðið vandamál í kjölfar einkenna LSR og vegna vanlíðunar sem henni fylgdi. ${ }^{36}$ Priðja algengasta fylgiröskun LSR er félagsfælni (37-39\%) og pá áráttu-og práhyggjuröskun (32-33\%). Tengsl hafa fundist milli LSR og félagsfælni, báðar raskanir lýsa sér í miklum félagskvíða og skömm og pjást sjúklingar af ótta við að peim verði hafnað eða strítt. Félagsfælni virðist pó hefjast fyrr en LSR. 37,38

Í fyrrnefndri rannsókn Phillips og félaga á úrtaki fólks með LSR, kom í ljós að 9\% pátttakenda voru einungis með LSR, 22\% voru greindir með eina aðra geðröskun auk LSR, 29\% voru greindir með tvær aðrar geðraskanir auk LSR og 43\% voru greindir með prjár eða fleiri geðraskanir auk LSR. ${ }^{37}$ Pví fleiri fylgiraskanir sem einstaklingur pjáist af, peim mun neikvæðari áhrif hafa pær á líf hans. ${ }^{4,37}$ 


\section{Árangur meðferðar}

Próun meðferðar við LSR og mat á árangri meðferðar er skemur á veg komin en hvað varðar margar aðrar pekktari geðraskanir. ${ }^{39}$ Flestar rannsóknir sem hafa verið gerðar á meðferð við LSR nota lítil úrtök og eru með tiltölulega stutta eftirfylgni og langtímaáhrif meðferðar eru lítið pekkt. Í eftirtöldum rannsóknum var að jafnaði metið hvort árangur sé klínískt marktækur. Miðað er við minnst $30 \%$ lækkun á stigafjölda á mælitækinu Body Dysmorphic Disorder Modification of the Yale-Brown Obsessive-Compulsive Disorder Scale. Рað er klínískt viðtal sem metur alvarleika einkenna og var fyrst próað til að meta árangur meðferðar við áráttu- og práhyggjuröskun. ${ }^{40}$

\section{Sálræn meðferð}

Hugræn atferlismeðferð (HAM) er sú meðferð sem talin er vera árangursríkust við einkennum LSR. HAM fyrir LSR-sjúklinga beinist að hegðun og hugsunum sem viðhalda röskuninni og eru skjólstæðingum kenndar nýjar leiðir til að meta útlitstengdar hugsanir og draga úr áráttu- og öryggishegðun. ${ }^{41}$ Safngreining (meta-analysis) var gerð á 7 rannsóknum sem könnuðu áhrif HAM á LSR, par af voru 6 rannsóknir á fullorðnum einstaklingum með LSR og ein á börnum og unglingum. ${ }^{42}$ Í öllum tilfellum dró HAM talsvert úr einkennum LSR samanborið við hópinn á biðlista (delta $=-1,22,95 \%$ öryggisbil (ÖB): $-1,66$ til $-0,79 ; p<0,001$ ). Niðurstöður úr premur rannsóknum bentu til pess að áhrif HAM væru enn til staðar tveimur til fjórum mánuðum síðar. Fimm af pessum rannsóknum sýndu að einnig dró úr einkennum punglyndis í kjölfar meðferðar, samanborið við biðlistahópinn (delta $=-0,49$, $95 \%$ ÖB $=-0,76$ til $-0,22 ; p<0,001)$ og í fjórum peirra jókst innsæi pátttakenda (delta $=-0,56,95 \%$ ÖB $=-0,93$ til $-0,19 ; \mathrm{p}=0,003$ ). ${ }^{42}$

Aðeins ein rannsókn hefur verið gerð par sem HAM var borin saman við annars konar sálfræðilega meðferð, pað er kvíðastjórnun. Pátttakendur voru 46 og eftir 12 vikur af meðferð (HAM eða kvíðastjórnun) kom í ljós að HAM bar meiri árangur við að draga úr einkennum LSR, og var pessi árangur enn til staðar 16 vikum síðar. Einnig bentu niðurstöður til pess að alvarleiki LSR-einkenna í upphafi virtist ekki hafa áhrif á árangur, HAM er einnig árangursrík fyrir pá sem eru verr haldnir af LSR. Einnig kom í ljós að peir pátttakendur sem fengu HAM öðluðust aukið innsæi um eigið útlit og meiri lífsgæði. ${ }^{43}$

Tvær rannsóknir hafa verið gerðar á HAM meðal ungmenna með LSR. Í peirri fyrri var pátttakendum raðað tilviljunarkennt í hópa, annar hópurinn fékk HAM í 14 skipti og samanburðarhópur fékk fræðslu (psychoeducation) um LSR og leiðir til að takast á við hana. Í tilraunahóp náðu 40\% pátttakenda árangri í samanburði við 7\% í samanburðarhópi. Pessi árangur HAM er pó ekki jafn góður og aðrar rannsóknir hafa sýnt, en pað gæti verið vegna pess hve stutt meðferðin var eða vegna pess að LSR hjá ungmennum er oft mjög alvarleg. ${ }^{44}$ Í seinni rannsókninni náðu 35\% pátttakenda sem fengu HAM árangri strax eftir meðferð og 12 mánuðum seinna höfðu 50\% pátttakenda náð árangri. ${ }^{45}$ Pörf er á að rannsaka frekari meðferð við LSR hjá ungmennum pví röskunin kemur yfirleitt fram á peim aldri og nauðsynlegt er að geta brugðist við röskuninni strax og ádur en hún byrjar að hafa neikvæð áhrif á líf einstaklingsins..$^{14,44}$
Pær rannsóknir sem hafa verið gerðar benda til pess að HAM við LSR sé yfirleitt árangursrík, en mikilvægt er að framkvæma fleiri rannsóknir á stærri úrtökum og fylgja skjólstæðingum lengur eftir en hefur verið gert hingað til, svo hægt sé að meta betur langtímaárangur HAM. ${ }^{46}$ Prátt fyrir hátt algengi LSR vantar rannsóknir á ólíkri meðferð við henni.

\section{Lyfjameðferð}

Rannsóknir á lyfjameðferð hafa aðallega beinst að serótónínendurupptökuhamlandi lyfjum (SRI; serotonin reuptake inhibitors), eins og flúoxetíni, flúvoxamíni, cítalópram og escítalópram, en hafa einnig beinst að príhringlaga lyfjum einsog klómípramíni.,47-53 Tvær rannsóknir með tilraunahópum hafa verið gerðar til að kanna áhrif lyfja á LSR. Í peirri fyrri var 67 pátttakendum raðað af handahófi í hópa sem ýmist fengu SRI-lyfið flúoxetín eða lyfleysu í tvíblindri rannsókn. Benda niðurstöður til pess að flúoxetín dragi frekar úr einkennum LSR en lyfleysa, par sem 53\% sýndu jákvæða svörun við flúoxetíni og $18 \%$ sýndu jákvæða svörun við lyfleysu, og var sá munur marktækur $\left(X^{2}=8,8 ; \mathrm{p}=0,03\right){ }^{54}$ Sú seinni var einnig tvíblind rannsókn og gefa niðurstöður til kynna að klómípramín skili meiri árangri en punglyndislyfið desípramín við að draga úr einkennum LSR. ${ }^{49}$ Fjórar rannsóknir án samanburðarhóps könnuðu áhrif flúvoxamíns, cítalóprams og escítalópram sog sýndu niðurstöður að pau drógu úr LSR-einkennum hjá 6383\% pátttakanda. ${ }^{50-53}$ Einnig hefur komið fram í framsýnni tvíblindri rannsókn að escítalópram getur komið í veg fyrir endurkomu LSR-einkenna. ${ }^{55}$

Niðurstöður ofangreindra rannsókna benda til pess að lyfjameðferð dragi úr LSR-einkennum, svo sem útlitsáhyggjum sjúklinga og áráttuhegðun en einnig úr punglyndiseinkennum og kvíða. Einnig hefur hún góð áhrif á félagslega virkni sjúklinga, sjálfsvígshugsanir og virðist auka almenn lífsgæði. LSR-sjúklingar purfa oft stærri skammta af SRI-lyfjum en til dæmis peir sem eru punglyndir, og geta pví aukaverkanir verið fleiri.,47 Pað getur tekið allt að 12-16 vikur fyrir SRI-lyf að virka á einkenni LSR, og meðaltími af fyrstu svörun við lyfjum er í kringum 4-9 vikur. ${ }^{56}$ Ekki hefur enn verið gerð framskyggn rannsókn sem ber saman hópa sem fá mismunandi SRI-lyf en pau lyf sem hafa mest verið rannsökuð og sýna góðan árangur eru escítalópram og flúoxetín. Klómípramín er oft notað pegar SRI-lyf hafa ekki komið að gagni. ${ }^{56}$ Einnig vantar enn rannsóknir sem bera saman lyfjameðferð og sálræna meðferð og sampætta lyfja- og sálræna meðferð, og pví er hvorki hægt að fullyrða hvor meðferðin sé árangursríkari né hvort sampætt meðferð bæti einhverju við meðferðarárangur.

\section{Fegrunaraðgerðir og húðmeðferð}

Sjúklingar sem pjást af LSR sækja oft í annars konar meðferð (svo sem lýtaaðgerðir eða húðaðgerðir) til að laga „lýti“ sitt, með misgóðum árangri. ${ }^{57}$ Stærsta rannsóknin á pessu sviði var á 289 einstaklingum með LSR, en par höfðu 76\% leitað eftir meðferð hjá húð- og lýtalæknum og 66\% höfðu fengið slíka meðferð. Pá var algengara að leita til húðlækna (45\%) en til lýtalækna (23\%), enda er húð sá líkamshluti sem flestir sem pjást af LSR hafa áhyggjur af. Hjá $72 \%$ sjúklinga bar meðferðin lítinn sem engan árangur og 
engin breyting var á LSR-einkennum sjúklinga, 11\% greindu frá breytingum á heildareinkennum LSR til hins betra en 16\% sjúklinganna töldu sig verr stadda en fyrir meðferð. ${ }^{57}$ Aðrar rannsóknir hafa einnig bent til pess að sjúklingum geti liðið enn verr eftir að hafa hlotið meðferð sem byggist ekki á gagnreyndri sálrænni meðferð eða lyfjameðferð, til dæmis hjá húð- eða lýtalækni. ${ }^{58,59}$

Spurningakönnun var gerð meðal 265 lýtalækna og töldu $84 \%$ peirra að peir hefðu framkvæmt aðgerð á sjúklingi með LSR, og í aðeins $1 \%$ tilvika töldu peir að aðgerðin hefði leitt til bata á LSR. Ennfremur höfðu 40\% upplifað hótun frá sjúklingi með LSR, ýmist um lögsókn eða barsmíðar. Rúmlega $80 \%$ pátttakenda sögðust hafa uppgötvað að viðkomandi sjúklingur væri með LSR eftir að peir höfðu framkvæmt aðgerðina á honum. Meðal peirra sem höfðu framkvæmt aðgerð á LSR-sjúklingi töldu 43\% að sjúklingurinn væri uppteknari af líkamshlutanum eftir aðgerð og 39\% töldu að sjúklingurinn hefði orðið upptekinn af öðrum líkamshluta eftir aðgerðina. ${ }^{60}$ Misræmi virðist vera milli skynjaðs bata sjúklinga á LSR og raunverulegs bata á einkennum LSR eftir fegrunaraðgerðir, 35\% sjúklinga töldu að sér liði betur eftir aðgerðina en aðeins 1,3\% greindi frá minni einkennum eftir aðgerð. ${ }^{61}$ Pegar á heildina er litið benda niðurstöður til pess að fegrunaraðgerðir leiði sjaldnast til bata á einkennum LSR, og geti jafnvel verið skaðlegar. Раð er pví sérlega mikilvægt að læknar og annað heilbrigðisstarfsfólk skimi fyrir LSR og vísi peim sem skimast með röskunina til sálfræðings eða geðlæknis sem pekkir til röskunarinnar.

\section{Hvernig má skima fyrir LSR og greina röskunina?}

Auðvelt er að skima fyrir einkennum röskunarinnar með pví að fara eftir viðmiðum DSM-5 fyrir LSR. ${ }^{1}$ Spurningalistinn Body Dysmorphic Disorder Questionnaire (BDDQ) er hentugt mælitæki sem Katharine Phillips setti saman til að skima fyrir einkennum LSR. Listinn er sjálfsmatskvarði og samanstendur af fjórum atriðum sem byggja á greiningarviðmiðum DSM-IV, eins og sjá má í íslenskri pýðingu Andra Steinpórs Björnssonar og Ásmundar Gunnarssonar sem birt er á heimasíðu Læknablaðsins (sjá viðauka við pessa grein). Fólk er líklega með LSR ef pað svarar báðum liðum í spurningu 1 játandi, og ef pað svarar einum eða fleirum liðum spurningar 3 játandi, og ef pað svarar liðum b) eða c) í spurningu 4 játandi. Ef fólk er líklega með LSR er mikilvægt að hvetja fólk til að leita til sálfræðings eða geðlæknis til að fá greiningu og frekara mat. BDDQ-spurningalistinn var hannaður til að skima fyrir LSR og rannsókn á 66 pátttakendum á geðdeild gefur til kynna að mælitækið hafi 100\% næmi og um 89\% sértæki. ${ }^{2}$ Pótt erfitt sé að bera saman pýði í ólíkum löndum má nefna að réttmæti BDDQspurningalistans var metið í almennu pýði í Svípjóð, listinn hafði $94 \%$ næmi og $90 \%$ sértæki, $71 \%$ af peim pátttakendum sem skimuðust með LSR samkvæmt BDDQ voru greindir með röskunina í klínísku greiningarviðtali. ${ }^{62}$ Mælitæki til að greina LSR er klíníska viðtalið Body Dysmorphic Disorder Diagnostic Module (BDD-DM) sem Katharine Phillips samdi. Um er að ræða hálfstaðlað greiningarviðtal sem samanstendur af 6 atriðum sem byggja á greiningarviðmiðum DSM-IV LSR og benda fyrri rannsóknir til pess að viðtalið hafi góða próffræðilega eiginleika. ${ }^{63}$ Mikilvægt er að greiningaraðili hafi hlotið pjálfun í notkun klínískra greiningarviðtala (til dæmis sem hluti af pjálfun í klínískri sálfræði eða geðlæknisfræði), meðal annars reynslu af helstu mismunagreiningum og góða pekkingu á sálmeinafræði, par með talið LSR. Mælt er með pví að greiningaraðilinn hljóti pjálfun hjá leiðbeinanda sem hefur fengið pjálfun í notkun mælitækisins. Greiningaraðili metur meðal annars hvort útlitsgalli er sýnilegur, og hvort einkennin séu betur skýrð með annarri geðröskun. BDD-DM er einnig til í íslenskri pýðingu Andra Steinpórs Björnssonar og Ásmundar Gunnarssonar, og í uppfærðri útgáfu miðað við DSM-5, eins og sjá má á heimasíðu Læknablaðsins (sjá viðauka við pessa grein). Greiningaraðili metur fyrst hvort peir útlitsgallar sem einstaklingur upplifir séu sýnilegir. Viðkomandi parf að hafa virkar hugsanir í um klukkutíma á dag eða meira til pess að ná viðmiði $\mathrm{A}$, hafa einhvern tíma sýnt einhvers konar áráttukennda hegðun eða öryggishegðun (svo sem að horfa í spegil eða biðja aðra um hughreystingu vegna útlits) sem svar við áleitnum hugsunum um eigið útlit, til pess að ná viðmiði $\mathrm{B}$, til að ná viðmiði C purfa hugsanirnar að hafa valdið mikilli vanlíðan eða haft neikvæð áhrif á líf pessa einstaklings (svo sem neikvæð áhrif á félagsleg samskipti eða getu til að sinna vinnu). Að lokum er LSR ekki greind ef einkennin eru betur skýrð með annarri geðröskun. Erfiðast er að greina LSR frá átröskunum, og má nefna að LSR er yfirleitt ekki greind ef viðkomandi sjúklingur hefur einungis áhyggjur af lögun líkamans eða líkamsfitu og röskun á matarvenjum er helsta einkenni, og engin önnur LSR-einkenni eiga við. Eins og áður hefur komið fram einkennast hugsanir í LSR yfirleitt af práhyggju og viðbrögð við peim hugsunum eru oft áráttukennd. Pessar hugsanir snúast jafnan um útlit og er áráttan svar við peim hugsunum, en hugsanir í áráttu- og práhyggjuröskun beinast að annars konar ótta, svo sem um að valda öðrum skaða. Einnig má nefna að húðkropp og hárplokk telst einungis hluti af LSR ef tilgangur hegðunarinnar er (að minnsta kosti í upphafi) að bæta pað sem skjólstæðingur lítur á sem líkamslýti (til dæmis slíta hár sem skjólstæðingi finnst ekki „líta rétt út“). Prátt fyrir að innsæi skjólstæðinga með LSR einkennist stundum af ranghugmyndum er að jafnaði auðvelt að greina á milli LSR og geðrofsraskana, enda eru önnur pemu í ranghugmyndum í peim síðarnefndu. Pað er mikilvægt að taka fram að fólk með LSR fær stundum ofsakvíðaköst, en pau teljast eingöngu vera hluti af LSR ef pau eru viðbrögð við ótta sem tengist röskuninni, og eru algengustu aðstæðurnar pegar fólki finnst aðrir vera að horfa á „líkamslýtið“, pegar pað horfir í spegil á pá líkamshluta sem pað er óánægt með, og við pað að vera í mikill birtu. ${ }^{64}$

\section{Samantekt og framtióarsýn}

Prátt fyrir hátt algengi LSR er hún vangreind í klínískum aðstæðum. Hún hefur alvarlegar afleiðingar í för með sér, eins og mikla vanvirkni, skert lífsgæði, punglyndi og mikla sjálfsvígshættu. Раð er pví mikilvægt að skima fyrir LSR og greina hana svo hægt sé að veita bestu meðferð við henni.

Раð meðferðarúrræði sem hefur mest verið rannsakað eru hugræn atferlismeðferð og lyfjameðferð með SRI-lyfjum. ${ }^{2,47}$ Niðurstöður rannsókna benda til pess að bæði HAM og meðferð með SRIlyfjum beri árangur við LSR.,242,47-53 Niðurstöður safngreiningar 
með rannsóknum par sem pátttakendur fengu ýmist HAM eða SRI-lyf voru pær að HAM og SRI bera sambærilegan árangur við LSR, en engin rannsókn hefur verið gerð sem metur muninn á hópum sem fá ýmist SRI-lyf eða HAM. ${ }^{48}$

prátt fyrir pann árangur sem HAM og lyfjameðferð hafa sýnt er mun algengara að sjúklingar með LSR leiti sér hjálpar til húðog lýtalæknis til að láta laga lýti sín. Peir trúa pví að petta séu raunveruleg lýti sem aðeins fást löguð með aðgerð. Rannsóknir benda til pess að slík meðferð beri ekki árangur, og geti leitt til pess að sjúklingi líði verr að lokinni aðgerð. Mikilvægt er pví fyrir húð- og lýtalækna að vera meðvitaðir um LSR, einkenni hennar og hvernig best sé að skima fyrir henni. ${ }^{57}$

Heilbrigðisstarfsmenn hérlendis purfa að pekkja helstu einkenni röskunarinnar pví algengt er að peir sem pjást af röskun- inni fái ekki rétta greiningu og par með ekki rétta meðferð. Eins er pörf á að auka pekkingu meðal almennings par sem fáir vita að LSR er raunveruleg geðröskun. Peir sem eru með LSR upplifa mikla skömm tengda röskuninni, og pví er mikilvægt að draga úr henni með aukinni pekkingu, meiri skilningi og auknum forvörnum. Brýnt er að próa fleiri meðferðarmöguleika fyrir sjúklinga með LSR. •að verður einungis gert með áframhaldandi rannsóknum á pessu sviði. Framtíðarrannsóknir ættu að leggja sérstaka áherslu á að rannsaka áhættupætti röskunarinnar sem og meðferð við LSR hjá ungmennum pví algengast er að röskunin komi fram um 12 ára aldur og nauðsynlegt er að geta brugðist við röskuninni strax. Jafnframt er mikilvægt að efla forvarnir við pessari algengu og oft alvarlegu geðröskun.

Viðauka er að finna við pessa grein á netinu.

\section{ENGLISH SUMMARY}

\section{Body dysmorphic disorder: Symptoms, prevalence, assessment and treatment}

\section{Hrefna Harðardóttir ${ }^{1}$ \\ Arna Hauksdóttir ${ }^{1}$ \\ Andri Steinpór Björnsson²}

Body dysmorphic disorder (BDD) is a relatively common disorder characterized by a preoccupation with nonexistent or slight defects in appearance. BDD usually begins during childhood or adolescence. The preoccupation with the perceived appearance defect typically occurs for many hours a day and is often followed by repetitive behaviours (for example mirror checking and skin picking). The weighted prevalence of BDD in a community sample

\begin{abstract}
is around $2 \%$, but it is higher in clinical settings and in cosmetic and dermatological settings. BDD leads to significant distress and/ or impairment at work or school and is highly comorbid with major depressive disorder, alcohol or substance use disorder, social anxiety disorder and obsessive compulsive disorder and often leads to suicidal ideation. Research suggests that cognitive behavioral therapy (CBT) and SSRI medication are most effective for BDD. However, cosmetic and dermatological treatments rarely improve $\mathrm{BDD}$, and are often harmful. This review contains information on how to screen and diagnose BDD. Further research on BDD and effective treatment for this often imparing disorder is needed.
\end{abstract}




\section{Heimildir}

1. American Psychiatric Association. Diagnostic and statistical manual of mental disorders (5. útgáfa). American Psychiatric Association, Washington DC 2013.

2. Phillips KA. The Broken Mirror: Understanding and Treating Body Dysmorphic Disorder: Oxford University Press 2005.

3. Phillips KA, Diaz SF. Gender differences in body dysmorphic disorder. J Nerv Ment Dis 1997; 185: 570-7.

4. Phillips KA, Menard W, Fay C, Weisberg R. Demographic characteristics, phenomenology, comorbidity, and family history in 200 individuals with body dysmorphic disorder. Psychosomatics 2005; 46: 317-25.

5. Phillips KA, McElroy SL, Keck PE Jr, Pope HG Jr, Hudson JI. Body dysmorphic disorder: 30 cases of imagined ugliness. Am J Psychiatry 1993; 150: 302-8.

6. Veale D, Riley S. Mirror, mirror on the wall, who is the ugliest of them all? The psychopathology of mirror gazing in body dysmorphic disorder. Behav Res Ther 2001; 39: 1381-93.

7. Phillips KA. Understanding body dysmorphic disorder: An essential guide. Oxford University Press, New York 2009.

8. Albertini RS, Phillips KA. Thirty-three cases of body dysmorphic disorder in children and adolescents. J Am Acad Child Adolesc Psychiatry 1999; 38: 453-9.

9. Phillips KA, Didie ER, Menard W, Pagano ME, Fay C, Weisberg RB. Clinical features of body dysmorphic disorder in adolescents and adults. Psychiatry Res 2006; 141 305-14.

10. American Psychiatric Association. Diagnostic and statistical manual of mental disorders : DSM-III-R (3. útgáfa). American Psychiatric Association. Washington 1987.

11. Phillips KA, Menard W, Pagano ME, Fay C, Stout RL. Delusional versus nondelusional body dysmorphic disorder: clinical features and course of illness. J Psychiat Res 2006; 40: 95-104

12. Eisen JL, Phillips KA, Coles ME, Rasmussen SA. Insight in Obsessive Compulsive Disorder and Body Dysmorphic Disorder. Compr Psychiatry 2004; 45; 10-5.

13. WHO. The ICD-10 Classification of Mental and Behavioural Disorders: Clinical Descriptions and Diagnostic Guidelines. World Health Organization, Genf 1992.

14. Björnsson AS, Didie ER, Grant JE, Menard W, Stalker E, Phillips KA. Age at onset and clinical correlates in body dysmorphic disorder. Compr Psychiatry 2013; 54: 893903.

15. Phillips KA, Menard W, Fay C. Gender similarities and differences in 200 individuals with body dysmorphic disorder. Compr Psychiatry 2006; 47: 77-87.

16. Conroy M, Menard W, Fleming-Ives K, Modha P, Cerullo $\mathrm{H}$, Phillips KA. Prevalence and clinical characteristics of body dysmorphic disorder in an adult inpatient setting. Gen Hosp Psychiatry 2008; 30: 67-72.

17. Grant JE, Kim SW, Crow SJ. Prevalence and clinical features of body dysmorphic disorder in adolescent and adult psychiatric inpatients. J Clin Psychiatry 2001; 62 517-22.

18. Dyl J, Kittler J, Phillips KA, Hunt JI. Body dysmorphic disorder and other clinically significant body image concerns in adolescent psychiatric inpatients: prevalence and clinical characteristics. Psychiatry Hum Dev 2006; 36 369-82.

19. Zimmerman M, Mattia JI. Body dysmorphic disorder in psychiatric outpatients: recognition, prevalence, comorbidity, demographic, and clinical correlates. Compr Psychiatry 1998; 39: 265-70.

20. Phillips KA, Nierenberg AA, Brendel G, Fava M Prevalence and clinical features of body dysmorphic disorder in atypical major depression. J Nerv Ment Dis 1996; 184: 125-9.

21. Veale D, Gledhill LJ, Christodoulou P, Hodsoll J. Body dysmorphic disorder in different settings: A systematic review and estimated weighted prevalence. Body Image 2016; 18: 168-86

22. Schieber K, Kollei I, de Zwaan M, Martin A. Classification of body dysmorphic disorder - What is the advantage of the new DSM-5 criteria? J Psychosom Res 2015; 78: 223-7.
23. Schneider SC, Turner CM, Mond J, Hudson JL. Prevalence and correlates of body dysmorphic disorder in a community sample of adolescents. Aust N Z J Psychiatry 2017; 51: 595-603.

24. Mayville S, Katz RC, Gipson MT, Cabral K. Assessing the Prevalence of Body Dysmorphic Disorder in an Ethnically Diverse Group of Adolescents. J Child Fam Stud 1999; 8: 357-62.

25. Björnsson AS, Magnúsdóttir S, Wessman I, Beard C, Lee J, Hearon BA, et al. Prevalence and Characteristics of Body Dysmorphic Disorder Among Patients in a Partial Hospital Program. J Nerv Ment Dis 2016; 204: 554-7.

26. Gunnarsson Á, Jónsdóttir SM, Björnsson AS. Líkamsskynjunarröskun: Algengi í átröskunarteymi Geðsviðs Landspítala - háskólasjúkrahúss. Sálfræðiritið 2014; 19: 93-106.

27. Snorrason Í, Smári J, Ólafsson RP. Húđkroppunarárátta: klínísk einkenni og tengsl við geðræn vandamál í úrtaki háskólanema. Sálfræðiritið 2009; 14: 103-13.

28. Björnsson A. Age at onset and clinical course of body dysmorphic disorder. Í Phillips KA (ritsti.): Body dysmorphic disorder: Advances in research and clinical practice (115-23). Oxford University Press, New York 2017.

29. Phillips KA, Grant JE, Siniscalchi JM, Stout R, Price LH. A retrospective follow-up study of body dysmorphic disorder. Compr Psychiatry 2005; 46: 315-21.

30. Björnsson AS, Dyck I, Moitra E, Stout RL, Weisberg RB, Keller MB, et al. The clinical course of body dysmorphic disorder in the Harvard/Brown Anxiety Research Project (HARP). J Nerv Ment Dis 2011; 199: 55-7.

31. Phillips KA, Menard W, Quinn E, Didie ER, Stout RL. A 4-year prospective observational follow-up study of course and predictors of course in body dysmorphic disorder. Psychol Med 2013; 43: 1109-17.

32. Rief W, Buhlmann U, Wilhelm S, Borkenhagen A, Brahler E. The prevalence of body dysmorphic disorder: A population-based survey. Psychol Med 2006; 36: 877-85.

33. Buhlmann $U$, Glaesmer $H$, Mewes R, Fama JM, Wilhelm $\mathrm{S}$, Brahler $\mathrm{E}$, et al. Updates on the prevalence of body dysmorphic disorder: a population-based survey. Psychiatry Res 2010; 178: 171-5.

34. Phillips KA, Coles ME, Menard W, Yen S, Fay C, Weisbers RB. Suicidal ideation and suicide attempts in body dysmorphic disorder. J Clin Psychiatry 2005; 66: 717-25.

35. Phillips KA, Menard W. Suicidality in Body Dysmorphic Disorder: A Prospective Study. Am J Psychiatry 2006; 163 : 1280-2.

36. Grant JE, Menard W, Pagano ME, Fay C, Phillips KA Substance use disorders in individuals with body dysmorphic disorder. J Clin Psychiatry 2005; 66; 309-16; quiz 404-5.

37. Gunstad I, Phillips KA. Axis I comorbidity in body dysmorphic disorder. Compr Psychiatry 2003; 44: 270-6.

38. Coles ME, Phillips KA, Menard W, Pagano ME, Fay C, Weisberg RB, et al. Body dysmorphic disorder and social phobia: cross-sectional and prospective data. Depress Anxiety 2006; 23: 26-33.

39. Wilhelm S, Phillips KA, Didie E, Buhlmann U, Greenberg JL, Fama JM, et al. Modular cognitive-behavioral therapy for body dysmorphic disorder: a randomized controlled trial. Behav Ther 2014; 45: 314-27.

40. Phillips KA, Hollander E, Rasmussen SA, Aronowitz BR, DeCaria C, Goodman WK. A severity rating scale for body dysmorphic disorder: development, reliability, and validity of a modified version of the Yale-Brown Obsessive Compulsive Scale. Psychopharmacol Bull 1997; 33: 17-22.

41. Veale D, Gournay K, Dryden W, Boocock A, Shah F, Willson $\mathrm{R}$, et al. Body dysmorphic disorder: a cognitive behavioural model and pilot randomised controlled trial. Behav Res Ther 1996; 34: 717-29.

42. Harrison A, Fernandez de la Cruz L, Enander J, Radua J, Mataix-Cols D. Cognitive-behavioral therapy for body dysmorphic disorder: A systematic review and meta-analysis of randomized controlled trials. Clin Psychol Rev; 2016; 48: 43-51.

43. Veale D, Anson M, Miles S, Pieta M, Costa A, Ellison N. Efficacy of cognitive behaviour therapy versus anxiety management for body dysmorphic disorder: a randomised controlled trial. Psychother Psychosom 2014; 83: 34153.
44. Mataix-Cols D, Fernandez de la Cruz L, Isomura K, Anson M, Turner C, Monzani B, et al. A Pilot Randomized Controlled Trial of Cognitive-Behavioral Therapy for Adolescents With Body Dysmorphic Disorder. J Am Acad Child Adolesc Psychiatry 2015; 54: 895-904.

45. Krebs G, de la Cruz LF, Monzani B, Bowyer L, Anson M, Cadman J, et al. Long-Term Outcomes of CognitiveBehavioral Therapy for Adolescent Body Dysmorphic Disorder. Behav Ther 2017; 48: 462-73.

46. McKay D. Two-Year Follow-Up of Behavioral Treatment and Maintenance for Body Dysmorphic Disorder. Behav Modif 1999; 23: 620-9.

47. Phillips KA, Hollander E. Treating Body Dysmorphic Disorder with Medication: Evidence, Misconceptions, and a Suggested Approach. Body Image 2008; 5: 13-27.

48. Ipser JC, Sander C, Stein DJ. Pharmacotherapy and psychotherapy for body dysmorphic disorder. Cochr Database Syst Rev 2009; 1: Cd005332.

49. Hollander E, Allen A, Kwon J, Aronowitz B, Schmeidler J, Wong $C$, et al. Clomipramine vs desipramine crossover trial in body dysmorphic disorder: selective efficacy of a serotonin reuptake inhibitor in imagined ugliness. Arch Gen Psychiatry 1999; 56: 1033-9.

50. Perugi G, Giannotti D, Di Vaio S, Frare F, Saettoni $\mathrm{M}$, Cassano GB. Fluvoxamine in the treatment of body dysmorphic disorder (dysmorphophobia). Int Clin Psychopharmacol 1996; 11: 247-54.

51. Phillips KA. An open-label study of escitalopram in body dysmorphic disorder. Int Clin Psychopharmacol 2006; 21: 177-9.

52. Phillips KA, Dwight MM, McElroy SL. Efficacy and safety of fluvoxamine in body dysmorphic disorder. J Clin Psychiatry 1998; 59: 165-71.

53. Phillips KA, Najjar F. An open-label study of citalopram in body dysmorphic disorder. J Clin Psychiatry 2003; 64: 715-20.

54. Phillips KA, Albertini RS, Rasmussen SA. A randomized placebo-controlled trial of fluoxetine in body dysmorphic disorder. Arch Gen Psychiatry 2002; 59: 381-8.

55. Phillips KA, Keshaviah A, Dougherty DD, Stout RL, Menard W, Wilhelm S. Pharmacotherapy Relapse Prevention in Body Dysmorphic Disorder: A DoubleBlind, Placebo-Controlled Trial. Am J Psychiatry 2016; 173 : 887-95.

56. Phillips KA (ritstj.). Pharmacotherapy and Other Somatic Treatments for Body Dysmorphic Disorder. Oxford University Press, 2017.

57. Phillips KA, Grant J, Siniscalchi J, Albertini RS. Surgical and nonpsychiatric medical treatment of patients with body dysmorphic disorder. Psychosomatics 2001; 42: 50410 .

58. Veale D. Outcome of cosmetic surgery and DIY' surgery in patients with body dysmorphic disorder. Psychiatric Bulletin 2000; 24: 218-20.

59. Veale D, Boocock A, Gournay K, Dryden W, Shah F, Willson R, et al. Body dysmorphic disorder. A survey of fifty cases. Br J Psychiatry 1996; 169: 196-201.

60. Sarwer DB. Awareness and identification of body dysmorphic disorder by aesthetic surgeons: results of a survey of American Society of Aesthetic Plastic Surgery members. Aesthet Surg J 2002; 22: 531-5.

61. Crerand CE, Phillips KA, Menard W, Fay C. Nonpsychiatric medical treatment of body dysmorphic disorder. Psychosomatics 2005; 46: 549-55.

62. Brohede S, Wingren G, Wijma B, Wijma K. Validation of the Body Dysmorphic Disorder Questionnaire in a community sample of Swedish women. Psychiatry Res 2013; 210: 647-52.

63. Phillips KA. Body Dysmorphic Disorder Diagnostic Module. McLean Hospital, Belmont, MA 1994.

64. Phillips KA, Menard W, Bjornsson AS. Cued panic attacks in body dysmorphic disorder. J Psychiatr Pract 2013; 19: 194-203. 